\title{
Phenolic compounds from Morus nigra regulate viability and apoptosis of pancreatic $\beta$-cells possibly via SERCA activity
}

Vladimir Heger ${ }^{\mathbf{a}, \mathbf{b}}$, Barbora Benesova ${ }^{\mathbf{a}, \mathbf{b}}$, Jana Viskupicova ${ }^{\mathbf{a}}$, Magdalena Majekova ${ }^{\mathbf{a}}$, Zoofishan Zoofishan $^{\mathrm{c}}$, Attila Hunyadi $^{\mathrm{c}}$, Lubica Horakova $^{\mathbf{a}^{*}}$

Corresponding author, e-mail address Lubica.Horakova@savba.sk

a Institute of Experimental Pharmacology and Toxicology, Centre of Experimental Medicine SAS, Dubravska cesta 9, 84101 Bratislava, Slovakia

${ }^{\mathbf{b}}$ Department of Biochemistry, Faculty of Natural Sciences, Comenius University in Bratislava, Mlynska dolina, Ilkovicova 6, 84215 Bratislava 4, Slovakia

${ }^{\mathbf{c}}$ Institute of Pharmacognosy, Interdisciplinary Excellence Centre, University of Szeged, Eötvös u. 6, 6720, Szeged, Hungary

\section{Supporting Information:}

\section{Details of Experimental Procedures}

\section{SERCA activity measurement}

SR vesicles $(1 \mathrm{mg}$ prot./ml) were added to the assay mixture (40 mM HEPES pH 7.2, $0.1 \mathrm{M}$ $\mathrm{KCl}, 5.1 \mathrm{mM} \mathrm{MgSO}$, $2.1 \mathrm{mM}$ ATP, $0.52 \mathrm{mM}$ phosphoenolpyruvate, $1 \mathrm{mM}$ EGTA, $0.15 \mathrm{mM}$ NADH, 7.5 IU of pyruvate kinase, 18 IU of lactate dehydrogenase) and incubated for 2 minutes with phenolic compounds $(10-70 \mu \mathrm{M})$ at $37^{\circ} \mathrm{C}, \mathrm{pH} 7.2$. The reaction was started by addition of $1 \mathrm{mM} \mathrm{CaCl}_{2}$ to the reaction mixture. The absorbance was recorded at $340 \mathrm{~nm}$ with a microplate reader (Infinite M200, Tecan, Switzerland).

\section{Labeling of SERCA1 in SR vesicles using FITC}

After incubation with compounds, FITC-ATPase labeling ratio of approximately 0.5:1.0 was performed. Stock solution of FITC $(6 \mathrm{mM})$ was prepared in dry dimethylformamide. SR (0.6 $\mathrm{mg}$ protein/ml) was diluted in the volume of $35 \mu \mathrm{l}$ of a HEPES buffer $(1 \mathrm{M} \mathrm{KCl}, 0.25 \mathrm{M}$ sucrose and $50 \mathrm{mM}$ HEPES, $\mathrm{pH} 8.0$ ). The final reaction mixture contained $2.5 \eta \mathrm{M}$ of FITC. The reaction mixture was left to stand at room temperature in dark for $1 \mathrm{~h}$ and consequently diluted with 250 $\mu 1$ of a Tris-buffer (0.2 M sucrose, $50 \mathrm{mM}$ Tris- $\mathrm{HCl}, \mathrm{pH} 7.0)$. Labeled samples were left to stand for $30 \mathrm{~min}$ at $37{ }^{\circ} \mathrm{C}$ and stored on ice until detection. Labeled protein $(15 \mu \mathrm{g})$ was added 
to $1 \mathrm{ml}$ of Tris-buffer $(5 \mathrm{mM} \mathrm{MgSO} 4,100 \mathrm{mM} \mathrm{KCl}, 25 \mu \mathrm{M}$ EGTA and $50 \mathrm{mM}$ Tris-maleate buffer, $\left.\mathrm{pH} 7.0,25^{\circ} \mathrm{C}\right)$.

\section{Culturing of beta-cells}

INS-1E insulinoma pancreatic beta-cell line (kindly provided by Prof. Claes Wollheim, University of Geneva) was cultured in RPMI 1640 (11 mM glucose, Sigma Aldrich). RPMI 1640 was supplemented with $100 \mathrm{U} / \mathrm{ml}$ penicillin, $100 \mu \mathrm{g} / \mathrm{ml}$ streptomycin, $2 \mathrm{mM} \mathrm{L-glutamine,}$ $1 \mathrm{mM}$ Na-pyruvate, $55 \mu \mathrm{M}$ 2-mercaptoethanol, $10 \mathrm{mM}$ HEPES, $1 \%$ non-essential amino acids, and $10 \%$ fetal bovine serum, $\mathrm{pH}$ 7.0-7.4. The cells were grown in a humidified incubator containing $5 \% \mathrm{CO} 2$ at $37{ }^{\circ} \mathrm{C}$. Lysis buffer contained $0.2 \mathrm{ml}$ per $1 \times 10^{6}$ cells $/ 25 \mathrm{~cm}^{2}$ flask containing $20 \mathrm{mM}$ Tris- $\mathrm{HCl}, 150 \mathrm{mM} \mathrm{NaCl}, 1 \mathrm{mM} \mathrm{Na} 2$ EDTA, $1 \mathrm{mM}$ EGTA, $1 \%$ Triton, 2.5 $\mathrm{mM}$ sodium pyrophosphate, $1 \mathrm{mM} \beta$-glycerophosphate, $1 \mathrm{mM} \mathrm{Na} 3 \mathrm{VO}_{4}$ and $1 \mu \mathrm{g} / \mathrm{ml}$ leupeptin. Cells were incubated with the $\mathrm{IC}_{50}$ concentrations of individual compounds for $24 \mathrm{~h}$ and then submitted to lysis in ice-cold lysis buffer. The cells were homogenized by passing the lysate through a syringe needle. The lysates were kept on ice for $10 \mathrm{~min}$ and then centrifuged for 10 min at $20160 \mathrm{RCF}$ and kept at $-30{ }^{\circ} \mathrm{C}$ until further use.

\section{Separation of proteins}

Laemmli buffer (25mM Tris, 1\% SDS, 0.192M glycine, $1 \%$ bromphenol blue, pH 6.8) containing freshly added 5\% mercaptoethanol was added to the protein samples. The samples were loaded onto an SDS-polyacrylamide gel (10\% separating, 4\% stacking gel). The separation was performed for $0.5 \mathrm{~h}$ at $50 \mathrm{~V}$ and then $1.5 \mathrm{~h}$ at $150 \mathrm{~V}$. After SDS-PAGE, the proteins were transferred to immobilon-P polyvinylidene fluoride (PVDF) membrane by semidry immunoblotting ( $250 \mathrm{~mA}$ for $30 \mathrm{~min}$ ). All incubations were performed in PBS, $0.1 \%$ Tween. The membrane with transferred proteins was blocked with 5\% fat-free dry milk for $2 \mathrm{~h}$ and then exposed to the monoclonal mouse IgG antibody against SERCA2 (IID8, AB 630230, sc-53010, Santa Cruz, USA 1:1 000 in 2.5\%, fat-free dry milk). All membranes were incubated with mouse anti- $\beta$-actin monoclonal antibody (AB 2714189, sc-47778, Santa Cruz, USA, 1:10 000). Goat anti-mouse IgG-HRP (AB631736, sc-2005, Santa Cruz, USA 1:10 000 in 2.5\%, fatfree dry milk) was used as a secondary antibody for both SERCA2b and $\beta$-actin. The bands were visualized using luminol (sc-2048, Santa Cruz, USA) as a chemiluminescent probe and analyzed by Amersham Imager 600 (GE Health Care Europe GmbH, Freiburg, Germany).

\section{Cytotoxicity assay (MTT)}


INS-1E cells were seeded in 96-microwell plates at a density of $5 \times 10^{4}$ cells per well. The cells were pre-incubated for $24 \mathrm{~h}$ with or without different concentrations of individual phenolic compounds $(1-200 \mu \mathrm{M}), 5 \% \mathrm{CO}_{2}$, at $37{ }^{\circ} \mathrm{C}$. MTT was added to achieve the final concentration of $0.5 \mathrm{mg} / \mathrm{ml}$ and after incubation over a period of $4 \mathrm{~h}$, solubilization buffer (10\% SDS in 0.01 $\mathrm{M} \mathrm{HCl}$ ) was added and let to stand for $15-17 \mathrm{~h}$ to solubilize the formazan formed.

\section{Detection of apoptosis}

INS-1E cells were harvested and resuspended in cold Krebs-Ringer Bicarbonate Buffer (KRBH) comprised of $140 \mathrm{mM} \mathrm{NaCl}, 3.6 \mathrm{mM} \mathrm{KCl}, 0.5 \mathrm{mM} \mathrm{NaH}_{2} \mathrm{PO}_{4}, 0.5 \mathrm{mM} \mathrm{MgSO}_{4}, 1.5$ $\mathrm{mM} \mathrm{CaCl}_{2}, 2 \mathrm{mM} \mathrm{NaHCO} 3,10 \mathrm{mM}$ HEPES, and $0.1 \%$ (w/v) bovine serum albumin. The cells were counted and the cell suspension was adjusted to $1 \times 10^{6}$ cells $/ \mathrm{ml}$ with KRBH buffer. FITC Annexin $(5 \mu \mathrm{l})$ and propidium iodide $(2 \mu \mathrm{l}$ of the $100 \mu \mathrm{g} / \mathrm{ml}$ PI stock solution) were added to each $100 \mu \mathrm{l}$ sample cell suspension and the cells were incubated for $15 \mathrm{~min}$ in the dark. Finally, $400 \mu \mathrm{l}$ of KRBH were added and the stained cells were analyzed by flow cytometry (Beckman Coulter, USA) using FL1 and FL3 channels. A total of 5000-gated events were analyzed per sample by flow cytometry.

\section{Release of insulin}

The secretory responses to glucose were measured in INS-1E cells, after 24 h-preincubation of beta-cells with individual compounds the cells were washed with glucose free KRBH buffer. Next, they were incubated for $30 \mathrm{~min}$ at $37^{\circ} \mathrm{C}$ in glucose free $\mathrm{KRBH}$ buffer and then for 30 min at $37{ }^{\circ} \mathrm{C}$ in $\mathrm{KRBH}$ buffer supplemented with $16.7 \mathrm{mM}$ glucose. After incubations, the supernatants were collected for insulin secretion, detected by RIA kit (Mercodia, Sweden) using rat insulin as standard. 